\title{
GLASBENI ARHIV STAREJŠIH ROKOPISOV V CERKVI SV. DANIJELA V CELJU
}

\author{
JANA ERJAVEC \\ Znanstvenoraziskovalni center SAZU, Ljubljana
}

\begin{abstract}
Izvleček: Prispevek predstavlja potek urejanja in evidentiranja glasbene zbirke starejših rokopisov iz arhiva Opatijsko-mestne župnije Celje (SI-Co) ter nekatere novosti o slogovni podobi ohranjene glasbe ter njenih najpomembnejših prepisovalcih. Napredek $v$ tehnologiji ter izboljšani raziskovalni pogoji so spodbudili ponovno obravnavo, ki je razkrila zanimiv, večplasten potencial za prihodnje poglobljene raziskave, zlasti zaradi sledi, ki nakazujejo na raznolik izvor gradiva in namembnost repertoarja.
\end{abstract}

Ključne besede: glasbeni katalogi, cerkev sv. Danijela v Celju, glasbeni rokopisi, glasba 18. stoletja, glasba 19. stoletja

\begin{abstract}
The article describes the process of organizing and cataloguing the collection of early music manuscripts held by the archive of Celje abbey and parish (SI-Co) and certain new discoveries regarding its stylistic composition and most notable copyists. Significant progress in technology and improved research conditions have prompted a fresh examination, which has revealed an intriguing, multi-faceted potential for future in-depth research, particularly on account of signs of a different provenance and purpose of the repertoire.
\end{abstract}

Keywords: music catalogues, church of St Daniel in Celje, music manuscripts, eighteenth-century music, nineteenth-century music

V arhivu Opatijsko-mestne župnije Celje (SI-Co) se je ohranila večja zbirka notnih rokopisov, nastalih v drugi polovici 18. stoletja in v 19. stoletju. Na obstoj zbirke je v osemdesetih letih prejšnjega stoletja stroko opozoril takratni celjski opat, nakar jo je leta 1981 pričel evidentirati Danilo Pokorn. ${ }^{1}$ Popisovanje in katalogiziranje zbirke je zaključil leta 1985 , izsledke ter prve domneve o zbirki pa javnosti prvič predstavil leta 1989 v Muzikološkem zborniku. ${ }^{2}$ Odtlej sta posamezne kompozicije iz zbirke natančneje analitično in primerjalno obravnavala dva raziskovalca: Aleš Nagode prepise maš Venčeslava Wratnyja (Ms. mus. 105-107), ${ }^{3}$ Radovan Škrjanc pa prepise skladb Missa ex $C$, MH 15 (Ms. mus. 32)

Razprava je nastala v okviru raziskovalnega programa »Raziskave slovenske glasbene preteklosti« (P6-0004) in raziskovalnega projekta $»$ Stare tradicije v novih oblačilih: glasbene in besedilne predelave v izvajalski praksi liturgične glasbe« (J6-1809), ki ju financira Javna agencija za raziskovalno dejavnost Republike Slovenije.

1 Letopis, zv. 32, 227.

2 Letopis, zv. 35, 196; Pokorn, »Glasbena zbirka«.

3 V magistrski nalogi »Šest latinskih maš Venčeslava Wratnyja« ter članku »Slavnostne maše 
in Missa Pastorella ex C, MH deest (Ms. mus. 33) Michaela Haydna, Missa Dominicalis in C (Ms. mus. 94) in Missa Solemnis in D (Ms. mus. 96) Johanna Baptista Vanhala ter Missa in F (Ms. mus. 67) Novotneka. ${ }^{4}$ Razlog za ponovno obravnavo celjskih muzikalij je posledica predvsem novih metodoloških prijemov, ki so se razvili zaradi izjemnega napredka v znanosti in tehnologiji. Prenovljeni katalog je lahko - skupaj s prvimi rezultati v nadaljevanju predstavljene statistične analize iz gradiva razbranih podatkov - izhodišče za nadaljnje raziskave glasbene preteklosti Celja, v primerjavi z nekaterimi drugimi štajerskimi hranišči primarnih glasbenih virov (Maribor, Ptuj) sicer skromnejšega, a zato nič manj pomembnega in zanimivega mesta.

Celotna rokopisna zbirka je bila v zadnjem času temeljito pregledana in urejena. Fizično gradivo je bilo ustrezno označeno in zaščiteno pred nadaljnjimi zunanjimi vplivi ter morebitnimi poškodbami. Danilo Pokorn je v okviru lastne obravnave 170 rokopisov uredil v 129 enot. Urejene skladbe je vložil v papirnate ovoje velikosti A4 ter jim dodelil signaturo. ${ }^{5}$ Fond je nato evidentiral v obliki klasičnega listkovnega kataloga. Neurejene, neidentificirane fragmente je vložil v poseben ovoj. V okviru tokratne obravnave so bile vse enote, vključno z doslej nerazvrščenimi fragmenti, ponovno pregledane in urejene. Številne skladbe, ki še niso bile identificirane ali pa so jim bili pripisani napačni avtorji, so bile uspešno identificirane, zahvaljujoč deloma brskalniku po glasbenih začetkih ali t. i. incipitih v okviru baze Répertoire International des Sources Musicales (RISM), deloma prosto dostopnim digitaliziranim libretom, ki so se izkazali za ključne pri ugotavljanju izvora mnogih odlomkov glasbeno-gledaliških del neznanih avtorjev. ${ }^{6}$ Skladbe so bile vložene v nove ovoje, dodeljene signature pa nadaljujejo številčenje Danila Pokorna. Oštevilčeni in označeni so bili tudi vsi foliji. ' Za dodatno zaščito so bile skladbe vložene $\mathrm{v}$ arhivske škatle, označene s kratkimi in preglednimi informacijami o vsebini. Rokopisna zbirka po najnovejši ureditvi šteje 165 enot. $^{8}$

Stanje gradiva se od osemdesetih let ni bistveno spremenilo: »Nekatere skladbe je nagrizel zob časa, izgubili so se jim posamezni glasovi ali jim manjkajo naslovne strani $[\ldots]$ in po ureditvi gradiva je ostalo dva zavoja neidentificiranih fragmentov (»membra disiecta «). $\ll^{9}$ Zaradi neustrezne zaščite - rokopisi so bili le zloženi na kup, nekateri povsem brez zaščite, drugi pa vloženi le v papirnati ovoj - je papir utrpel določene poškodbe.

Venčeslava Wratnyja« je obravnaval tri maše, katerih prepisi se nahajajo v celjski zbirki. Eno izmed njih, Mašo v A-duru (Ms. mus. 107), je nato leta 2000 prav tako transkribiral in revidiral za objavo v zbirki Monumenta artis musicae Sloveniae.

4 Škrjanc, »'Stylus rusticanus'«, 170-254.

5 Pri ugotavljanju avtorstva je večkrat prihajalo do napak, predvsem zaradi napačne navedbe avtorstva na naslovnici, manjkajoče navedbe ali izgubljene naslovnice.

6 Brskalnik je dostopen na spletnem naslovu https://opac.rism.info.

$7 \mathrm{Na}$ vse parte in partiture so bile s svinčnikom v zgornji desni kot recto strani folija zapisane zaporedne številke.

8 Vseh skladb (rokopisnih prepisov in morebitnih avtografov) je 215. Danilo Pokorn v Letopisu Slovenske akademije znanosti in umetnosti iz leta 1985 navaja 164 rokopisov, v članku »Glasbena zbirka« leta 1989 pa 170 rokopisov oz. 129 bibliografskih enot (189 skupaj z 19 tiski, ki v pričujočo obravnavo niso bili zajeti). Letopis, zv. 35, 196; Pokorn, »Glasbena zbirka«, 108, 114-119.

9 Pokorn, »Glasbena zbirka«, 108. 
Ponekod je zmečkan, strgan in ožgan, predvsem pa umazan od prahu, strjenega voska in žuželk. Prav tako ga je načela plesen. Zbirka je sicer preživela vsaj tri požare, najsilnejšega na jutro velikega četrtka, 5. aprila 1798, ko se je iz minoritskega samostana razširil tudi na poslopja opatije. ${ }^{10}$ Celoten rokopisni fond je bil tudi digitaliziran.

Evidentiranje je potekalo v skladu s smernicami, ki jih predpisuje RISM. ${ }^{11}$ Zajete so bile informacije o avtorju, morebitnemu prepisovalcu ali nekdanjemu lastniku, o naslovu skladbe, ki je bil zabeležen kot diplomatičen prepis in kot standardiziran naslov, prešteti parti in partiture, odvzete mere, pregledani ter opisani vodni znaki, stare signature in drugi zaznamki. Nenazadnje so bili izpisani glasbeni začetki (incipiti).

Podobno kot zbirke nekaterih drugih cerkvenih hranišč na vzhodu Slovenije (npr. knjižnice frančiškanskega samostana $\mathrm{v}$ Novem mestu) tudi glasbeno zbirko cerkve sv. Danijela ne sestavljajo le dela $\mathrm{z}$ duhovno vsebino. ${ }^{12}$ Večina kompozicij je sicer nastala neposredno za potrebe cerkvenega kora sv. Danijela, te pa dopolnjujejo številne posvetne kompozicije.

Izvirno posvetni repertoar, ki obsega približno tretjino vseh skladb (vključno z glasbenimi in vsebinskimi predelavami), je sestavljen skoraj izključno iz vokalno-instrumentalnih kompozicij. Prevladujejo odlomki iz glasbeno-gledaliških del (oper in spevoiger) z izvirnim besedilom v italijanščini ali nemščini. Pogosti so tudi nemški prevodi italijanskih libretov, ki so bili pri občinstvu v tem obdobju priljubljeni. ${ }^{13}$ Čeprav so dokazi o obstoju glasbeno-gledaliških prizadevanj domačinov ter morebitnih obiskih potujočih gledaliških skupin v Celju in njegovi okolici skopi, nakazuje samo število ohranjenih tovrstnih kompozicij na precejšnjo priljubljenost repertoarja tudi v tem delu dežele. ${ }^{14}$ Mnoge so bile celo predelane za izvedbo v cerkvenem okolju. Tovrstne vsebinske predelave, imenovane kontrafakture, ${ }^{15}$ so bile kljub prizadevanju tako Katoliške cerkve kot tudi posvetne oblasti za omejevanje posvetnih značilnosti v cerkveni glasbi precej priljubljene. ${ }^{16} \mathrm{O}$ priljubljenosti prakse podpisovanja novega liturgičnega besedila popularnim posvetnim kompozicijam

${ }^{10}$ Orožen, Celska kronika, 179-180; Orožen, Zgodovina Celja, 592.

${ }^{11}$ Smernice so na voljo le registriranim uporabnikom najnovejšega centralnega programa za popisovanje, imenovanega Muscat (http://muscat-project.org/). Program je pričela leta 2002 razvijati skupina RISM v Veliki Britaniji, nakar se ji je leta 2008 pridružila švicarska skupina RISM. Leta 2013 se je v razvojni proces vključila še Centralna redakcija RISM. Program je od leta 2016 na voljo celotni skupnosti RISM. Gre za odprtokodni, večjezični spletni program, ki deluje neodvisno od vrste operacijskega sistema. Povzeto po http://muscat-project.org/history. html.

${ }^{12}$ Venišnik, »Instrumental Music«, 93.

${ }^{13}$ Sivec, Opera na ljubljanskih odrih, 18.

${ }^{14}$ Andreas Gubo v kronološkem sprehodu skozi zgodovino Celja poroča o izvedbi priljubljene opere Die Schweizer Familie v treh dejanjih Josefa Weigla 21. aprila 1823. Gubo, Geschichte der Stadt Cilli, 348.

${ }^{15}$ Falck in Picker, »Contrafactum«.

${ }^{16} \mathrm{~V}$ 18. in 19. stoletju sta cerkvena in posvetna oblast večkrat posegli v cerkveno glasbo. Leta 1749 je papež Benedikt XIV. z okrožnico Annus qui pričel omejevati vpliv »posvetnih značilnosti« na cerkveno glasbo, v naslednjih desetletjih pa je sledilo še več podobnih ukrepov, med njimi dvorna odredba cesarice Marije Terezije leta 1754, ki je prepovedala določena glasbila v cerkvi, ter še posebej strog pravilnik za cerkveno glasbo papeža Pija IX. leta 1856, ki predstavlja dopolnjeno 
V 19. stoletju poroča lavantinski škof Anton Martin Slomšek (1800-1862). ${ }^{17} \mathrm{~V}$ osnutek predavanj o cerkveni umetnosti, ki ga je ok. leta 1860 pripravil za program teološkega študija v Mariboru, je zapisal, da so prepisovalci in prirejevalci najpogosteje prevzemali melodije iz opernih kompozicij, nakar so jim podpisali novo, liturgično besedilo, večkrat pa iz raznih opernih melodij sestavljali celotne maše. ${ }^{18}$ Določena dela v celjski zbirki so bila brez dvoma sprva kupljena ali prepisana z namenom, da se izvajajo v izvirni obliki, nakar jim je bilo po potrebi na istem ali pa ločenem foliju podpisano novo, duhovno besedilo, pri drugih delih pa paleografske lastnosti (ista pisava in tinta) jasno nakazujejo, da je bila skladba namenoma prepisana za izvedbo v cerkvenem okolju. Najdemo tudi skladbe $z$ več kontrafakturami in take, ki imajo ob izvirnem besedilu, najsi bo to italijansko ali nemško, podpisan še prevod v nemščini ali italijanščini. Poleg posvetnih je v zbirki še devet sicer po vsebini izvirno duhovnih kompozicij, ki z novim besedilom dobijo novo, liturgično funkcijo, npr. »Mit Staunen sieht das Wunderwerk« iz oratorija Stvarjenje Josepha Haydna ima poleg izvirnega besedila pripisano besedilo marijanske antifone Regina Caeli. Z raziskovanjem besedilnih predelav posvetne glasbe za izvajanje v cerkvenem okolju se v zadnjih letih ukvarja vse več raziskovalcev, še posebej na prostoru današnje Češke in Poljske pa je izpričanih več zbirk kontrafaktur. ${ }^{19}$

Mnoga posvetna dela na naslovnicah nosijo zaznamek v nemščini »Gesellschaft« (Društvo) ali »Gesellschaft Zilli« (Celjsko društvo). Najverjetneje so nekoč pripadala kateri od celjskih ljubiteljskih glasbenih družb, ki so delovale v 19. stoletju. ${ }^{20}$ Prva tovrstna organizacija naj bi bila ustanovljena že leta 1801 pod vodstvom Mihaela Neunerja, pisarja okrožnega urada bavarskega porekla. Razpadla je šest let kasneje, leta $1807 .{ }^{21}$ Leta 1836 ji je sledil Lavanter Musikverein (Lavantinsko glasbeno društvo). ${ }^{22}$ Ljubiteljski orkester je vodil Jožef Leitermeyer, ugledni učitelj godal. ${ }^{23}$ Družba je bila tesno povezana tako

različico leta 1842 izdanega ukaza papeževega vikarja in kardinala Patrizija. Höfler, Tokovi, 67, 88; Škulj, Odloki, 9-10.

${ }^{17}$ Anton Martin Slomšek je bil tik pred nastopom škofovske službe krajše obdobje celjski opat (od 25. aprila do 15. junija 1846). Grafenauer in Gspan, »Slomšek, Anton Martin«.

18 »Bald wurden aus den Opern und andern weltl. Musickstücken Arien eingeschmugelt, die Melodien mit Fugen, Trillern etc überladen, und nach u. nach jener unwürdige Operstil - der Rokko - u. Zapfstil eingeführt, der noch vorherscht. - So mancher Organist stoppelt aus mehr Opern eine Messe zusammen, der er den hl. Text unterlegt, und glorict damit in Kirchen der Städte u. Märkte.« Vsebina omenjenih predavanj zajema tudi poglavje o glasbi in cerkvenem petju (osmo poglavje z naslovom »Kirchlicher Gesang«, [str. 9, 6. odstavek]). Dokument se nahaja v Nadškofijskem arhivu Maribor (Zapuščine škofov, Slomšek Anton Martin, šk. 78).

${ }^{19}$ Gl.: Jeż, »Contrafacta of Operatic Arias«; Jonášová, »Kontrafakturen in der Böhmischen Kirchenmusik«.

${ }^{20}$ Pokorn, »Glasbena zbirka«, 108-112.

${ }^{21}$ Orožen, Celska kronika, 182, 186; Gubo, Geschichte der Stadt Cilli, 332, 337.

${ }^{22}$ Ignacij Orožen in Andreas Gubo kot ustanovitveno letnico navajata 1836, Janko Orožen pa 1832. Ker je slednji črpal predvsem iz Celske kronike Ignacija Orožna, gre morda za napako pri povzemanju. Orožen, Celska kronika, 198; Gubo, Geschichte der Stadt Cilli, 356; Orožen, Zgodovina Celja, 651.

${ }^{23}$ Med leti 1848-1854 vodja violinske šole ljubljanske Filharmonične družbe ter kasneje direktor Stanovskega gledališča. Zupančič, Razvoj violinske pedagogike, 20. 
s cerkvijo kot tudi s celjsko osnovno šolo, saj je nastala pod pokroviteljstvom lavantinskega škofa Ignaza Zimmermanna in celjskega ravnatelja in kateheta Simona Rudmaša. ${ }^{24}$ Delovala je do 18 . decembra $1846 .{ }^{25}$ Preostanek svojega imetja, vključno z glasbili, naj bi podarila cerkvi sv. Danijela. ${ }^{26}$ Podobnega društva nato ni bilo vse do leta 1888 , ko je bil ustanovljen Cillier Musikverein (Celjsko godbeno društvo), a so godbeniki ostali aktivni tudi v vmesnem obdobju. Z igranjem so spremljali posebne dogodke, eden takih je bila posvetitev novega celjskega opata Matije Voduška leta 1847, ko so »pred optiskoj hišoj [...] godli ino pevci prepevali «. ${ }^{27} \mathrm{~V}$ drugi polovici stoletja je bilo prav tako v porastu število pevskih društev. ${ }^{28}$
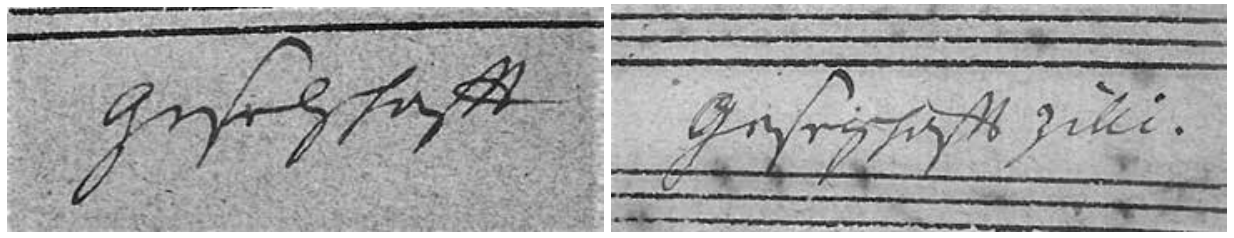

Sliki 1a (levo) in 1b (desno)

Zaznamek »Gesellschaft « v vseh primerih, razen v enem, spremlja stara signatura v obliki »Ni [zaporedna številka]« in se nekajkrat pojavi tudi s pripisom »Zilli«, nemško različico imena za Celje (Celje, Opatijska cerkev, Glasbeni arhiv, Ms. mus. 39 in 45; z dovoljenjem).

V celotni zbirki se pojavi le ena sama povsem instrumentalna kompozicija z naslovom L'irresistible (Ms. mus. 164), »polka brillante« za klavir madžarskega skladatelja, učitelja in pianista Emericha Szekelyja. Posvečena je neki »Louisze Jeszenak«.

Razumljivo je v zbirki najbolje zastopana duhovna glasba. Ta je bila kupljena in pripeljana v Celje ali pa prepisana na celjskem koru. Med liturgičnimi kompozicijami so najštevilčnejše uglasbitve mašnega ordinarija, sledijo uglasbitve posameznih spevov mašnega proprija (ofertoriji, graduali in sekvence) ter posameznih besedil oficija (antifon, himnusov, psalmov), litanije, več uglasbitev besedila Tantum ergo ter en sam ciklus skladb za večernice. Izbor liturgično nevezanih skladb je sestavljen iz duhovnih pesmi ter odlomkov iz oratorija Stvarjenje Josepha Haydna. Pri vsem tem gre tako za skromna dela, namenjena manjšim zasedbam, kakor tudi ambiciozneje zasnovane slavnostne maše, ki presegajo dolžino običajnega nedeljskega bogoslužja.

Zbirka odraža za to obdobje in prostor značilno raznovrstnost, ki se kaže v raznolikem izvoru ohranjenega repertoarja. Zastopani so avtorji, ki so bili rojeni ali pa so delovali na območjih današnje Avstrije, Češke, Francije, Hrvaške, Italije, Madžarske, Nemčije, Portugalske, Rusije, Španije (Katalonije) ter Brazilije, pa tudi skladatelji, ki so delovali v okviru današnjega slovenskega ozemlja. Med slednje sodijo Pellegrino Dalfiume, član

${ }^{24}$ Orožen, Celska kronika, 198.

${ }^{25}$ Matija Vodušek, ravnatelj celjske glavne šole, navaja več razlogov za neuspeh: notranja nesoglasja, nezadovoljstvo strank, neprijetne formalnosti, neustrezno glasbeno vodstvo in pomanjkanje smisla za glasbo pri celjskem prebivalstvu. Orožen, Zgodovina Celja, 651-652.

${ }^{26}$ Pokorn, »Glasbena zbirka«, 109.

${ }^{27}$ Orožen, Celska kronika, 202.

${ }^{28}$ Zajc-Cizelj, »Društveno življenje«, 215-216. 
Filharmonične akademije v Bologni, ki naj bi med letoma 1790 in (najkasneje) 1792 zasedal mesto violinista in vodje cerkvenega kora ljubljanske stolnice ter vodje šentjakobskega kora:;9 Anton Höller, organist ljubljanske stolnice med letoma 1800 in 1826 ter aktivni član in skladatelj ljubljanske Filharmonične družbe; ${ }^{30}$ Venčeslav Wratny, skladatelj češkega ali slovaškega porekla, ki je kot glasbenik med letoma 1794 in 1804 deloval v ljubljanski stolnici in bil eden aktivnejših skladateljev posvetne in cerkvene glasbe na Slovenskem; ${ }^{31}$ ter neznani Ignaz Sentscher, čigar ime se sicer pojavi med darovalci v prvem katalogu muzikalij ljubljanske Filharmonične družbe iz leta 1804, ne najdemo pa ga na seznamu njenih članov. ${ }^{32}$ Med ostalimi avtorji so predvsem predstavniki druge polovice 18 . in prve polovice 19. stoletja, vse od svetovno znanih predstavnikov dunajskega klasicizma (bratov Josepha in Michaela Haydna, Wolfganga Amadeusa Mozarta, Ludwiga van Beethovna, Antonia Salierija idr.) ter operne ustvarjalnosti (Gioachina Rossinija, Petra Winterja, Vicenteja Martín y Solerja idr.), do lokalnih ter neznanih ustvarjalcev (Joseph Tomanik, Martin Heimerich, Josephus Antonius Laucher idr.). Sicer jasno razberljivo, a popolnoma neznano ime v gradivu je Giuseppe Assigal, nepotrjeni pa so še štirje avtorji, ki so navedeni le s priimkom: Novotný, Novotnek, Müller in Eisenböck (ali Weisenböck).

Več oseb, zaslužnih za nastanek in oblikovanje glasbene zbirke opatijske cerkve sv. Danijela, je bilo zaposlenih v celjskih izobraževalnih ustanovah. Cerkveni organisti so bili namreč pogosto tudi učitelji, združitev obeh služb v Celju pa v virih prvič zasledimo na začetku 18. stoletja. ${ }^{33}$ Na seznamu ljudi, ki so med letoma 1777 in 1909 učiteljevali na celjski glavni in dekliški šoli, so vsaj štiri osebe, ki so prispevale k oblikovanju obravnavanih muzikalij: Barth. Baader (Ms. mus. 103/1, 103/2 in 103/3), Franz Faß1 (Ms. mus. 191), nedvomno pa po številu rokopisov izstopata Benedikt Schluga (Sluga) in Anton Zinauer. ${ }^{34}$

$Z$ Benediktom Schlugo je zagotovo povezana vsaj tretjina vseh enot. Te brez izjeme nosijo njegovo ime na naslovnicah, kjer se pojavi v sledečih oblikah: »ad me Benedictum Schluga «, »ad me Benedictum Slugga «, »Schluga« in »Benedicti Schluga«. Po lastnem pričevanju je bil rojen na Koroškem v kraju Žabnice v Kanalski dolini (nemško Staifnitz, danes Camporosso v Italiji) leta $1745 .{ }^{35}$ Že pred uveljavitvijo prvega osnovnošolskega zakona Marije Terezije naj bi deloval na javni učni ustanovi v hiši poleg farne cerkve, po ustanovitvi trirazredne glavne šole (nem. Hauptschule) 9. junija 1777 pa je bil zaposlen v prvem učiteljskem zboru te ustanove. ${ }^{36}$ Sluga, »posvetni učitelj izboljšane učne metode,

${ }^{29}$ Höfler, Tokovi, 84-86; Cvetko, Zgodovina glasbene umetnosti, 34-38.

${ }^{30}$ Höfler, Tokovi, 123, 131, 134; Cvetko, Slovenska glasba, 230; Trček, Potujoči glasbeniki.

${ }^{31}$ Cvetko, Zgodovina glasbene umetnosti, 162; Nagode, »Slavnostne maše«, 52.

${ }^{32}$ Cvetko, Zgodovina glasbene umetnosti, 91; Železnik, Repertoarne smernice.

${ }^{33}$ Orožen, Zgodovina Celja, 635.

${ }^{34}$ Zajc-Cizelj, Osnovna šola Celje, 129-132.

${ }^{35}$ Po poročanju Johanna Schmuta sta med rojstvi v župniji Žabnice med letoma 1740 in 1750 zabeležena le dva novorojenčka s priimkom Schluga, a nista poimenovana niti Benedikt, niti Vinzenz, kot je Schluga imenovan v navajanem viru. V rojstnih knjigah župnije v Pokloštru (nemško Arnoldstein) na Koroškem, od koder naj bi Schluga prihajal po poročanju Janka Orožna, pa za isto obdobje ni prav nobenega podatka o rojstvu otroka s priimkom Schluga. Schmut, »Über das Volksschulwesen um 1800«, 25; Orožen, Zgodovina Celja, 637.

${ }^{36}$ Zajc-Cizelj, Osnovna šola Celje, 7, 129. 
ki je že dotlej poučeval na stari celjski šoli ter se poslej javlja (poleg organista) kot 'regens chori’, tj. kot dirigent « ${ }^{37}$ je nato leta 1810 nasledil prvega ravnatelja glavne šole, minoritskega patra Mansueta Zanggerla, ter vodil šolo vse do upokojitve leta $1820 .{ }^{38} \mathrm{Umrl}$ je leta $1834 .{ }^{39}$ Prepisal je vsaj petinsedemdeset enot duhovnih in posvetnih kompozicij, prav tako je avtor več kontrafaktur.
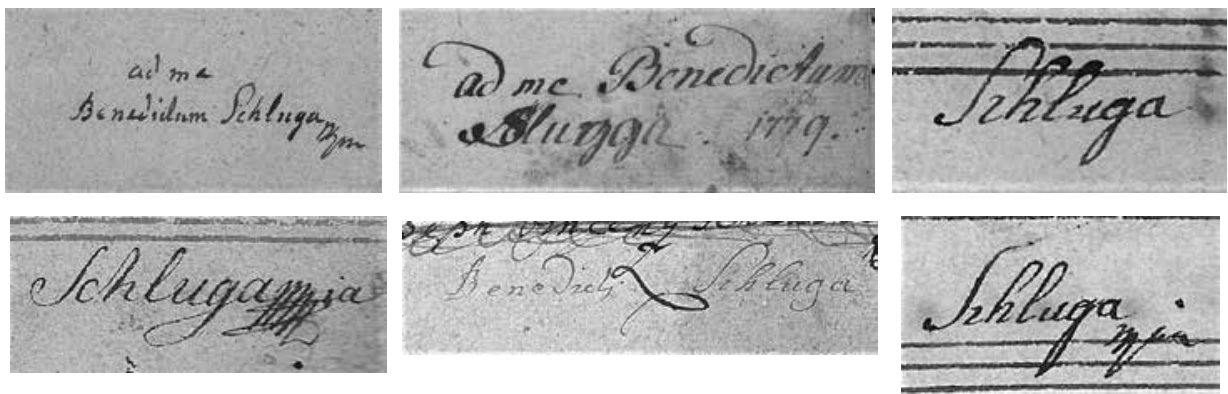

Slike 2a-2e (od leve proti desni)

Različice podpisa Benedikta Sluge (Celje, Opatijska cerkev, Glasbeni arhiv, Ms. mus. 9c, 32, 39 (zgoraj) in Ms. mus. 45, 86a, 130 (spodaj); z dovoljenjem).

Tako kot Schluga je bil organist cerkve sv. Danijela tudi Anton Zinauer. ${ }^{40}$ Ta je nasledil Karla Köppla (1785-1850), priljubljenega učitelja in organista, ki mu je bilo celo podeljeno častno meščanstvo, v okviru obravnavane zbirke pa ga kljub njegovemu pridobljenemu ugledu ne zasledimo. ${ }^{41}$ Zinauer je služboval tudi kot učitelj petja in glasbe. ${ }^{42}$ Iz njegovih rokopisov (22 jih je podpisanih) lahko s pomočjo datumov in letnic, ki jih je precej redno beležil, vsaj okvirno določimo čas njegovega službovanja v cerkvi sv. Danijela. Najstarejša letnica je 1839 (Ms. mus. 117), najmlajša pa 1853 (Ms. mus. 17), torej je na koru deloval vsaj 14 let. Najpogosteje se podpisuje z imenom in priimkom, občasno tudi le s priimkom ali z začetnicama A. Z. Na določenih enotah je poleg imena v nemščini pripisal še »Eigenthum« (last) ali »Schullehrer« oz. »Lehrer« (učitelj).

Za nastanek zbirke so zaslužne tudi osebnosti, ki so delovale zunaj Celja. Trije prepisovalci so se na naslovnico (nekateri tudi na posamezne parte) podpisali z manu propria. Avtor kopij pod signaturami Ms. mus. 18, 99, 134 in 146 je Joseph Stiller, čigar ime redno spremlja cena, kar botruje teoriji, da kopije niso nastale v Celju, temveč so bile morda kupljene ter prinesene v Celje. Ms. mus. 130 je vsaj delno prepisala oseba po

${ }^{37}$ Orožen, Zgodovina Celja, 637.

${ }^{38}$ Ibid., 639; Gubo, Geschichte der Stadt Cilli, 299.

${ }^{39}$ Nagode, $»$ Revizijsko poročilo«, IX.

${ }^{40}$ Orožen, Zgodovina Celja, 641.

${ }^{41} »$ Karl Köppel, geboren zu Cilli, zuerst als Gehilfslehrer und dann 1811 als wirklicher Lehrer angestellt, wurde im Jahr 1849 mit dem goldenen Verdienst Medaille dekoriert und starb als Meister in der Orgel, ein allgemein beliebter Mann und Ehrenbürger von Cilli im Jahr 1850.« Navedeno po seznamu učiteljev celjskih mestnih šol med leti 1777-1909 (iz ZAC, fond MŠC, fasc. 32, sig. 32/324), objavljenem v publikaciji Ivanke Zajc-Cizelj, Osnovna šola Celje, 129. S presežniki o Köpplu poroča tudi Andreas Gubo, Geschichte der Stadt Cilli, 371.

${ }^{42}$ Orožen, Zgodovina Celja, 641. 


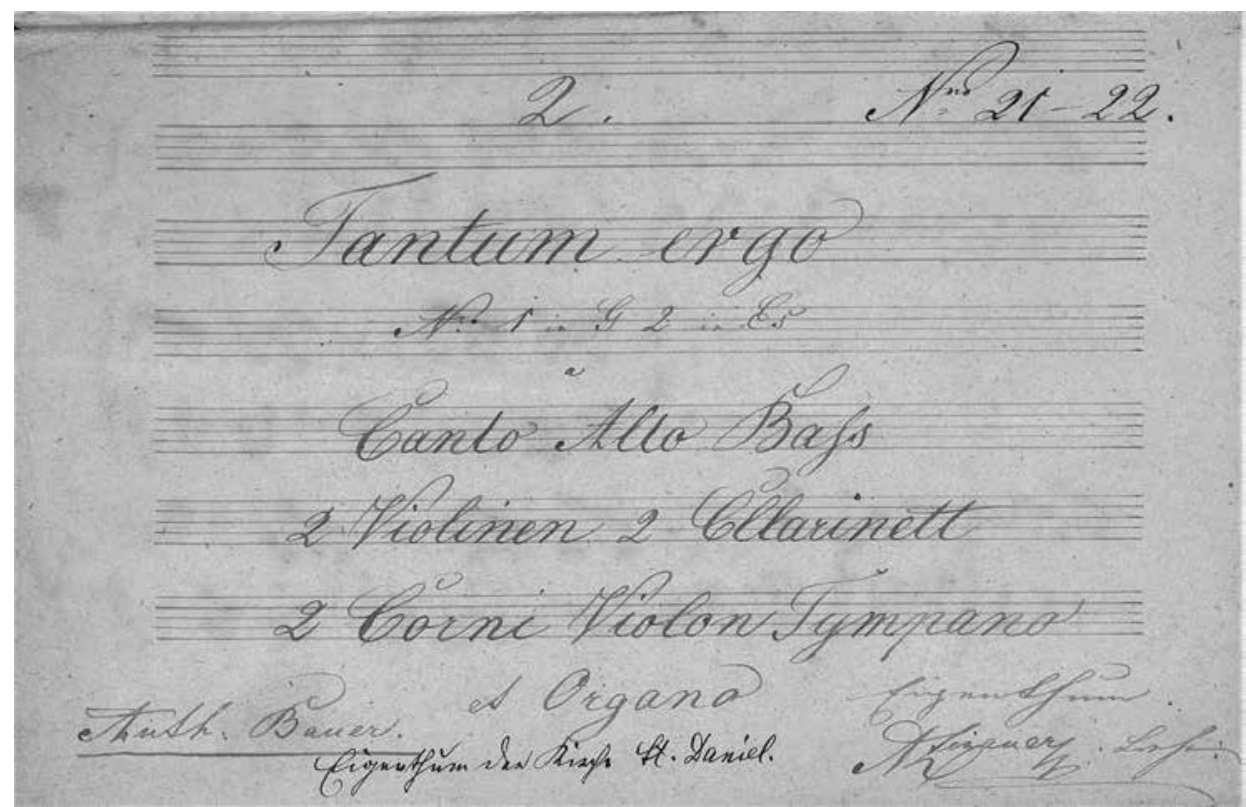

\section{Slika 3}

Naslovnica enega izmed rokopisov Antona Zinauerja. Njegov podpis je v spodnjem desnem kotu, s pripisom »Eigenthum« in »Lehrer«. Levo od podpisa je zaznamek »Eigenthum der Kirche St. Daniel.« (last cerkve sv. Danijela), v zgornjem desnem kotu pa sta stari signaturi (Celje, Opatijska cerkev, Glasbeni arhiv, Ms. mus. 4a; z dovoljenjem).

imenu Joseph Vincenz Schencher, skladba za klavir Emerica Szekelyja pod signaturo Ms. mus. 164 pa nosi ime Wildt. Čeprav pri naslovnicah Ms. mus. 24 in 153 ni imen, pa jih izdaja značilni, umetelno okrašeni rokopisni slog beneškega kopista Giuseppeja Baldana (1709-1786) oz. njegove delavnice. Kopija, ki je nastala le eno leto pred njegovo smrtjo, na naslovnici navaja beneško gledališče San Moisè, ki je bil pogost naročnik del Baldanove delavnice. ${ }^{43}$

Zbirka morda vsebuje tudi nekaj unikatov. Partitura pod signaturo Ms. mus. 37b je skoraj zagotovo avtograf na Češkem rojenega in v Gradcu delujočega skladatelja Martina Heimericha, ${ }^{44}$ Ms. mus. 125 je avtograf že omenjenega Ignaza Sentscherja, rokopisa Ms. mus. 20b in 20c (skupna naslovnica) pa pripadata varaždinskemu skladatelju Leopoldu Ebnerju.

${ }^{43}$ Kacin, Žiga Zois, 77.

${ }^{44}$ Janes, »Heimerich«. 

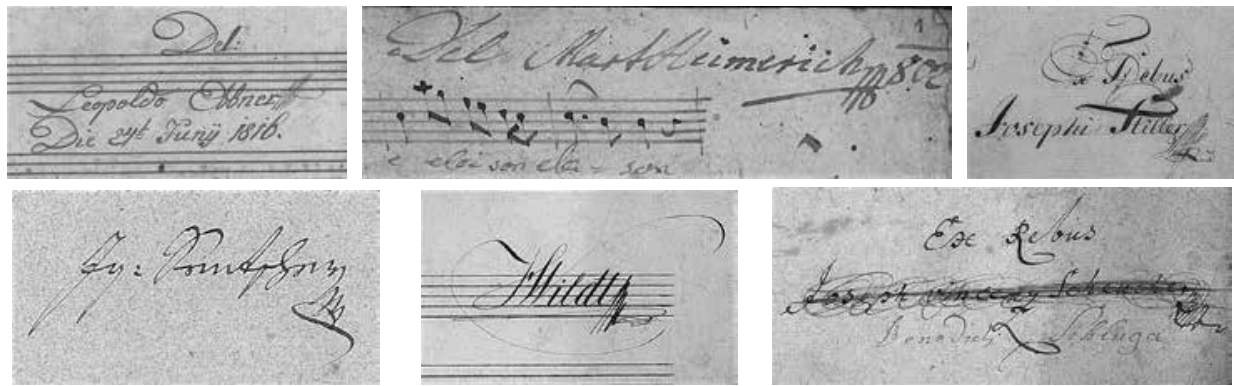

Slike 4a-4e (od leve proti desni)

Manu propria nekaterih skladateljev in prepisovalcev v SI-Co (Celje, Opatijska cerkev, Glasbeni arhiv, Ms. mus. 20b, 37, 99 (zgoraj) in Ms. mus. 130, 125, 164 (spodaj); z dovoljenjem).

Med najbolj enigmatičnimi je prisotnost žiga jezuitskega kolegija v Gorici na skoraj četrtini rokopisov v zbirki. Z ukinitvijo Oglejskega patriarhata in razdelitvijo njegovega teritorija leta 1751 je Savinjski arhidiakonat, od leta 1715 združen z mestno župnijo Celje, pripadel novoustanovljeni Goriški nadškofiji ter pod njeno pristojnostjo ostal vse do preureditve škofijskih meja med leti 1786-1789, nakar je pripadel lavantinski škofiji s sedežem v Št. Andražu na Koroškem. ${ }^{45}$ Kljub obstoječi zgodovinski povezanosti med sicer precej oddaljenima mestoma pa skladbe z žigom vseeno niso mogle nastati v okviru Družbe Jezusove v Gorici. Jezuitska pedagoška ustanova je bila namreč, kot mnoge druge cerkvene ustanove časa, leta 1773 ukinjena v okviru cerkvenih reform Jožefa II., večina skladb na papirju, označenih z žigom, pa je nastala šele po tej prelomni letnici. Alternativno pojasnilo je v svojem prispevku iz leta 1989 podal že Danilo Pokorn, ki je menil, da bi lahko bil ožigosani, a prazni papir prinesen v Celje, kjer je bil nato uporabljen. ${ }^{46}$

Za popolno sliko arhiva bo v prihodnosti potreben še pregled 19 tiskanih enot oziroma 74 tiskanih zvezkov, ki v pričujočo raziskavo zaradi časovne omejitve niso bili zajeti. Posledično bo tudi katalog v mednarodni spletni zbirki RISM objavljen šele po zaključenem pregledu celotne zbirke. Tiski sicer predstavljajo skromnejši delež

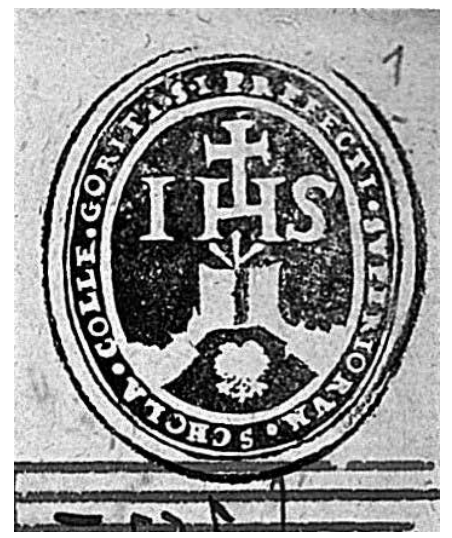

Slika 5

Žig goriškega jezuitskega kolegija (Celje, Opatijska cerkev, Glasbeni arhiv, Ms. mus. 105b; z dovoljenjem). zbirke. Gre predvsem za zvezke cerkvenega repertoarja, natisnjene in izdane v augsburški založniški hiši Lotter, znani po bogati ponudbi del južnonemških skladateljev katoliške cerkvene glasbe. ${ }^{47}$ Poleg teh, ki jih je v svoj seznam muzikalij uvrstil Danilo Pokorn, navaja seznam arhiva Opatijsko-mestne župnije iz leta

\footnotetext{
${ }^{45}$ Volčjak, »Preurejanje škofijskih meja«, 23; Richter, »Savinjski arhidiakonat«, 106-109.

${ }^{46}$ Pokorn, »Glasbena zbirka«, 108.

${ }^{47}$ Pokorn, »Glasbena zbirka«, 112; Layer, »Lotter«.
} 
1973 še večje število tiskov, ki pa sicer segajo v pozno 19. ter v 20. stoletje. ${ }^{48}$ Naknadno je bil odkrit še zajeten zavoj rokopisnih fragmentov iz druge polovice 18. ter iz 19. stoletja, ki pa ga bo treba še raziskati.

\section{Viri in literatura}

\section{ROKOPISNO ARHIVSKO GRADIVO}

Celje, Opatijska cerkev, Glasbeni arhiv (SI-Co), Ms. mus. 1-165.

Maribor, Nadškofijski arhiv, Zapuščine škofov, Slomšek Anton Martin, šk. 78.

\section{LITERATURA}

Cvetko, Dragotin. Slovenska glasba v evropskem prostoru. Ljubljana: Slovenska matica, 1991.

_ Zgodovina glasbene umetnosti na Slovenskem. Zv. 2. Ljubljana: Državna založba Slovenije, 1959.

Falck, Robert, in Martin Picker. »Contrafactum«. V: Grove Music Online. Obiskano 2. marca 2020. https://doi.org/10.1093/gmo/9781561592630.article.06361.

Grafenauer, Ivan in Alfonz Gspan. »Slomšek, Anton Martin«. V: Slovenska biografija. Obiskano 29. maja 2020. http://www.slovenska-biografija.si/.

Gubo, Andreas. Geschichte der Stadt Cilli vom Ursprung bis auf die Gegenwart. Graz: U. Mosers, 1909.

Höfler, Janez. Tokovi glasbene kulture na Slovenskem od začetkov do 19. stoletja. Ljubljana: Mladinska knjiga, 1970.

Janes, Susanne. »Heimerich (Heimrich, Heimbrich, Heinrich), Martin Andreas«. V: Oesterreichisches Musiklexikon online. Obiskano 2. marca 2020. https:/www. musiklexikon.ac.at.

Jeż, Tomasz. »Contrafacta of Operatic Arias among the Dominicans of Baroque Silesia«. De musica disserenda 11, št. 1-2 (2015): 147-162. https://doi.org/10.3986/dmd11.1-2.09.

Jonášová, Milada. »Kontrafakturen in der Böhmischen Kirchenmusik des 18. Jahrhunderts«. Musicologica Brunensia 49, št. 2 (2014): 107-126. https://doi.org/10.5817/MB2014-2-8.

Kacin, Marija. Žiga Zois in italijansko gledališče. Trst: samozaložba, 2013.

Layer, Adolf. »Lotter«. V: Grove Music Online. Obiskano 17. marca 2020. https://doi. org/10.1093/gmo/9781561592630.article.17021.

Nagode, Aleš. »Revizijsko poročilo«. V: Missa in A Venceslava Wratnya, IX-X. Monumenta artis musicae Sloveniae 39. Ljubljana: SAZU, Muzikološki inštitut ZRC SAZU, 2000. . »Slavnostne maše Venčeslava Wratnyja«. Muzikološki zbornik 32 (1996): 51-60. https://doi.org/10.4312/mz.32.1.51-60.

${ }^{48}$ Gre za zvezke mašnih kompozicij (tako v slovenščini kot v latinščini), maš za umrle, Marijinih, svetniških, adventnih, božičnih, postnih in velikonočnih pesmi, spevov za različne posebne priložnosti (podelitve zakramentov, darovanja) ter instrumentalnih preludijev večinoma slovenskih skladateljev. 
. »Šest latinskih maš Venčeslava Wratnyja«. Magistrsko delo, Univerza v Ljubljani, 1994.

Orožen, Ignacij. Celska kronika. Celje: J. Jeretin, 1854.

Orožen, Janko. Zgodovina Celja in okolice. Zv. 1, Od začetka do leta 1848. Celje: Kulturna skupnost, 1971.

Pokorn, Danilo. »Glasbena zbirka opatijske cerkve sv. Danijela v Celju«. Muzikološki zbornik 25 (1989): 107-120. https://doi.org/10.4312/mz.25.1.107-120.

Richter, Jakob. »Savinjski arhidiakonat in njegov konec«. Časopis za zgodovino in narodopisje 2 (1966): 104-112.

Schmut, Johann. »Über das Volksschulwesen um 1800: Aus der Gedenkschrift des Cillier Hauptschullehrers Vinzenz Schluga«. V: Beiträge zur Österreich: Erziehungsund Schulgeschichte, zv. 12, uredila Österr. Gruppe der Gesellschaft für deutsche Erziehungs- und Schulgeschichte, 25-49. Dunaj: K. u. k. Hof-Buchdruckerei und Hof-Verlagsbuchhandlung Carl Fromme, 1910.

Sivec, Jože. Opera na ljubljanskih odrih od klasicizma do 20. stoletja: izbrana poglavja. Ljubljana: Založba ZRC, ZRC SAZU, 2010.

Slovenska akademija znanosti in umetnosti. Letopis. Zv. 32 (1981). Ljubljana: SAZU, 1982. - Letopis. Zv. 35 (1984). Ljubljana: SAZU, 1985.

Škrjanc, Radovan. » 'Stylus rusticanus' v cerkveni glasbi na Slovenskem od sredine 18. do sredine 19. stoletja«. Doktorska disertacija, Univerza v Ljubljani, 2008.

Škulj, Edo. Odloki o cerkveni glasbi: ob stoletnici Pijevega motu proprija. Ljubljana: Družina, 2003.

Trček, Katarina. Potujoči glasbeniki: glasbene migracije v 17. in 18. stoletju, povezane s prostorom današnje Republike Slovenije. Slovenska glasbena dediščina 4. Ljubljana: Muzikološki inštitut ZRC SAZU, 2018. http://ezb.ijs.si/fedora/get/ezmono:pggm/ VIEW/.

Venišnik, Vesna. »Instrumental Music and Franciscan Liturgy«. Muzikološki zbornik 50, št. 2 (2014): 93-99. https://doi.org/10.4312/mz.50.2.93-99.

Volčjak, Jure. »Preurejanje škofijskih meja na Kranjskem sredi 18. stoletja: predlog združitve goriške nadškofije in ljubljanske škofije iz leta 1758«. V: Historični seminar, zv. 12, uredili Katarina Šter in Mojca Žagar Karer, 9-39. Ljubljana: Založba ZRC, ZRC SAZU, 2016.

Zajc-Cizelj, Ivanka. »Društveno življenje v Celju do leta 1918«. V: Iz zgodovine Celja, zv. 2, 1848-1918, uredila Marija Počivavšek, 206-236. Celje: Muzej novejše zgodovine, 1998.

. Osnovna šola Celje: 1777-1919. Celje: Zgodovinski arhiv, 2000.

Zupančič, Maruša. Razvoj violinske pedagogike in šolstva na Slovenskem od začetka 19. stoletja do začetka druge svetovne vojne. Ljubljana: Znanstvena založba Filozofske fakultete Univerze v Ljubljani, 2013. https://doi.org/10.4312/9789612375669.

Železnik, Sara. Repertoarne smernice Filharmonične družbe v Ljubljani: katalogi muzikalij Filharmonične družbe. Glasbena preteklost na Slovenskem. Ljubljana: Znanstvena založba Filozofske fakultete Univerze v Ljubljani, 2014. https://doi. org/10.4312/9789612376369. 


\title{
THE COLLECTION OF EARLY MUSIC MANUSCRIPTS AT THE CHURCH OF ST DANIEL IN CELJE
}

\author{
Summary
}

The article describes new discoveries regarding the collection of early music manuscripts from the archive of Celje abbey and parish, adjacent to the church of St Daniel. The manuscripts have been thoroughly examined, arranged and catalogued in the RISM online database. A statistical analysis of the data extracted from the material regarding copyists, possible former owners, old shelfmarks, stamps and other notes on covers, parts and scores has revealed certain facts about the provenance and function of some of the compositions, while others require further investigation.

Dating approximately to the second half of the eighteenth and the nineteenth centuries, the music in the collection is mostly religious, although a significant portion is of secular origin, consisting predominantly of excerpts taken from contemporary theatrical musical genres. Many of the latter have been textually adapted to fit a liturgical performing context. The compositions belong to a variety of composers ranging from world-famous representatives of the Viennese Classical period (Joseph Haydn, Wolfgang Amadeus Mozart, Ludwig van Beethoven, Antonio Salieri) and opera (Gioachino Rossini, Peter Winter etc.) to composers active locally (Karl Wenzel Wratny, Anton Höller etc.). Among the many indicated names of scribes and former owners, two stand out: Benedictus Schluga and Anton Zinauer, both of whom employed as organists and regentes chori at the church of St Daniel. They also held positions as general school and music teachers at the local Kreishauptschule (a secular elementary education institution established in Celje in 1776). At least twenty-five compositions, marked "Gesellschaft" or "Gesellschaft Zilli", are most likely connected to one or other of the two local lay music societies operating during the first half of the nineteenth century, the first being the Cillier Musikverein, active between 1801 and 1807, and the second the Lavanter Musikverein, active between 1836 and 1846. More enigmatic is the presence of the stamp of the Jesuit college in Gorizia. Since the dissolution of the Jesuit order and its institutions, including the Gorizia college, preceded the creation of most of the pieces on paper with that stamp, the general assumption is that the church of St Daniel somehow acquired the blank paper bearing the stamp and subsequently put it to use.

Simplified access to a straightforward and comprehensive catalogue of the SI-Co manuscript collection will assist future research endeavours to conduct precise and indepth investigations into the music of eighteenth- and nineteenth-century Celje and its surroundings, thereby enabling the further expansion of our general understanding of music within the geographical area of modern Slovenia during the "short eighteenth" and "long nineteenth" centuries. 